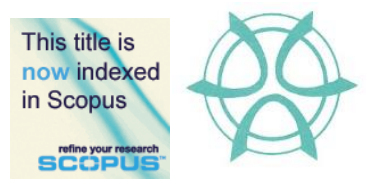

PLANNING MALAYSIA:

Journal of the Malaysian Institute of Planners

SPECIAL ISSUE V (2016), Page 77 - 88

\title{
THE CHALLENGE OF LABOUR SHORTAGE FOR SUSTAINABLE CONSTRUCTION
}

\author{
Faizul Azli Mohd-Rahim ${ }^{1}$, Nurul Safwah Mohd-Yusoff ${ }^{2}$, Wang Chen ${ }^{3}$, \\ Nurshuhada Zainon $^{4}$, Sumiani Yusoff ${ }^{5} \&$ Rafikullah Deraman $^{6}$ \\ ${ }^{1,2,3,4}$ Centre for Building, Construction, \& Tropical Architecture \\ Faculty of Built Environment \\ UNIVERSITY OF MALAYA \\ ${ }^{5}$ Department of Civil Engineering \\ Faculty of Engineering \\ UNIVERSITY OF MALAYA \\ ${ }^{6}$ Department of Building and Construction Engineering \\ Faculty of Civil and Environmental Engineering \\ UNIVERSITI TUN HUSSEIN ONN MALAYSIA
}

\begin{abstract}
In line with the principle of sustainable development, construction projects ought to be developed to bring benefits across all aspects, namely economic, social, and environmental. One the other hand, being a complex, fragmented and schedule driven industry, construction projects are frequently subject to problems that constrain their execution. Since construction is a labour intensive industry, the shortage of labour has become the crucial risks that hindering the construction project in achieving sustainability. This paper, in reviewing the concept of sustainable construction, also addresses the influential factors concerning the labour shortages in the construction industry and discusses how these challenges can be managed in producing sustainable construction labours.
\end{abstract}

Keyword: sustainable construction; labour shortage; technical education; vocational training 
Faizul Azli, Nurul Safwah, Wang Chen, Nurshuhada Zainon, Sumiani Yusoff \& Rafikullah Deraman

The Challenge of Labour Shortage for Sustainable Construction

\section{INTRODUCTION}

United Nation's Brundtland Commission's report (1987) defined sustainable development as the development that meets the needs of the present without compromising the ability of future generations to meet their own needs (Suliman \& Omran, 2009). The principle of sustainability is based on the idea that society should use the available resources on a scale consistent with the ability of future generations to meet their own needs (Zimmerman, 2005). During the United Nations' World Summit on Sustainable Development in Johannesburg in 2002, the basic definition of sustainable development has been refined to emphasize the collective responsibility to advance and strengthen the interdependent and mutually reinforcing pillars of sustainable development, namely the economic development, social development and environmental sustainability at every levels (e.g. local, national, regional and global) (Delnavaz, 2012).

Therefore, the key issue for sustainable development is the integration of different aspects of sustainability in three main aspects which are the social, economic, and environmental. The relationship between these aspects can be shown graphically by a Venn diagram (Figure 1) composed of three overlapping circles with each circle representing a different aspect (Lozano, 2008). The three overlapping circles symbolize how the core of sustainability requires equal consideration of all aspects where every decision towards solving the problem or improvement has an impact on these three aspects.

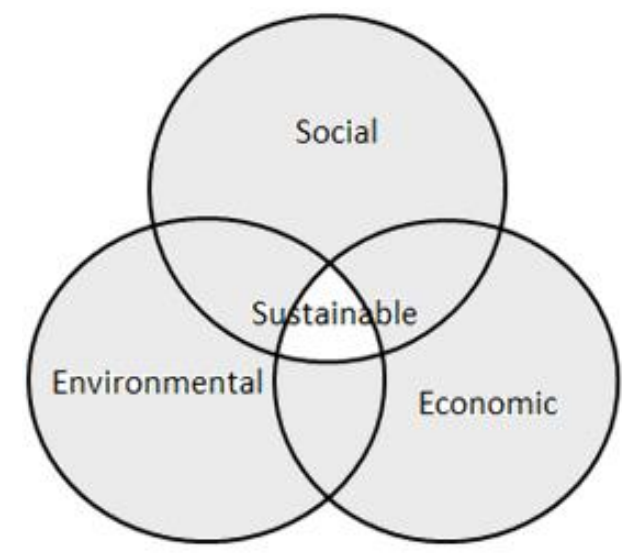

Figure 1: Venn diagram of the three pillars of sustainable development Source:(Lozano, 2008)

Construction industry is considered to be a major productive industry in Malaysia. For example, in 2014, this industry accounts around $3.9 \%$ of the Malaysia's total Gross Domestic Product (GDP) (Malaysia Productivity Corporation, 2015). The total value of construction work done in the second quarter 2014 recorded a double-digit growth of $10.8 \%$ year-on-year to RM25.2 
PLANNING MALAYSIA

Sustainable Urban Development

billion (Department of Statistics Malaysia, 2014). These developments has brought significant impacts to the Malaysia's economy and also resulted in other implications especially to the environment and social aspect of the country. This industry occupies the focal position in the economic development (Oseghale et al., 2015) and has created a lot of occupations opportunities to boost up the country's economy.

The construction industry is one of the sectors that play a significant role in the socio-economic growth of a country. Apart from being a major contributor to the overall GDP of a country, it is also responsible for providing the necessary infrastructure to improve the quality of life of a nation. Hence, in order to achieve sustainable development, it is fundamentally crucial for the construction industry to adopt sustainability concept, since it has significant direct and indirect links with the principal of sustainability (Bourdeau, 1999). For example, construction industry consumes high amount of resources, so improving its quality has a significant effect on the sustainability of the whole society (Huovila \& Koskela, 1998).

Horvath (2004) states that about $40 \%$ of the world's resource and energy use is linked to the construction and maintenance of buildings. This concern was responded by the sustainable construction practices, a more sustainable way than the conventional construction practice (Hussin et al., 2013).

In order to perform construction projects, labours are one of essential key factor important factors in successive of construction project management. Numerous of construction project have been failed and unsuccessful due to the labour factor. Windapo (2016) emphasizes where projects failures happen due to insufficient of skilful or qualified tradesmen. The level of supply of skilled tradesmen is attributed to the lack of high-quality basic education, the state of the economy, compulsory certification of worker and an ageing workforce. Besides, he found there is a significant relationship between skilled labour shortages and the requirement that labour be certified and that work output is unsatisfactory when there is no certification requirement. For better understanding, the term of labours are defined as skilful and unskilful worker generally work in construction field.

Ahmed et al., (2003), categorize their finding into two categories where internal causes (client, contractor and consultant) and external causes which are beyond the control of the organization. In our paper, as we stressed the contractor cause is about labour managing. Again, Assaf \& Al-Hejji (2006), conducted a study in construction industry of Saudi Arabia and reported critical causes of delay related to contractor, constructor and client in bigger construction projects. In general, to evaluate the workers quality and contribution in construction field can be assess by Performance analysis. Table 1.0 states the factors that lead to the failure of a construction projects due the labour factors. 
Faizul Azli, Nurul Safwah, Wang Chen, Nurshuhada Zainon, Sumiani Yusoff \& Rafikullah Deraman

The Challenge of Labour Shortage for Sustainable Construction

The lack of labour in this industry needs to be taken seriously because it can affect the productivity of the construction projects (Othman, 2014). For example, Baloyi \& Bekker (2011) state that the issue of labour shortages have a significant impact on the construction of football stadiums during the 2010 FIFA World Cup in South Africa when it became the second and third factors of the time delays and cost overrun in the project construction. Therefore, this paper aims to review the concept of sustainable construction, by highlighting the influential factors concerning the labour shortages in the construction industry and discussing how these challenges can be managed in producing a sustainable construction labours.

\section{METHODOLOGY}

The research method adopted for this paper is mainly based on a literature review of "sustainable construction" and "labour shortage" in the construction industry. The keywords used in the literature search include sustainable development, sustainable construction, labour shortage, construction labour, skilled labour, workforce planning, and sustainable management. This paper performed a content analysis approach that involves cross-referencing various sources of information in order to identify the challenge of labour shortage in construction industry. The literature analysis revealed 16 factors that influence the availability of labours in the construction industry. Although this paper places emphasis upon sustainable construction industry, the literature review, however the facts not limited to construction industry barely. This paper, in reviewing the sustainable construction concept, explores the relationship between the two topics and discusses how these challenges can be managed in constructing sustainable construction essentially factor of labours.

\section{CHALLENGES IN SUSTAINABLE CONSTRUCTION}

Kibert (2005) has defined sustainable construction as "creating a healthy built environment using resource-efficient, ecologically based principles". A construction project is considered to be sustainable only when all the basic principles of sustainability are compatible with each other (Mateus \& Bragança, 2011). The basis for the whole process lies in balancing financial, environmental and operational considerations of a construction project (Suliman \& Omran, 2009). However, many issues of sustainability are interrelated, and the interaction of a construction project with its surroundings has significant impacts for mankind (Hussin et al., 2013). Being a complex, fragmented and schedule driven industry, construction projects always facing chronic problems such as poor quality, low productivity, time overrun, over-budget, shortage of workers, construction waste and others (Rahman et al., 2013).

In line with the principle of sustainable development, construction projects should be developed to bring benefits across all aspects, namely 
PLANNING MALAYSIA

Sustainable Urban Development

economic, social, and environmental. However, developing projects under the fundamental of sustainable construction is complex because the projects are frequently subject to problems that constrain their execution (Wang, 2014). One of the critical problems faces by the construction industry is labour shortages (Hamid et al., 2013; Healy et al., 2015). Since construction is a labour intensive industry, the shortage of labour has direct effect on project performance, especially in term of cost, time and quality (Hajela, 2012; Ibrahim, 2013; Jarkas \& Younes, 2014).

In most countries, labour costs comprise $30 \%$ to $50 \%$ of the overall project costs (Jarkas \& Younes, 2014) and hence they are regarded as an important resource of the efficiency and success of the construction project. Apart from the aims to minimize the resource depletion, reducing environmental degradation, and developing a healthy built environment, the fundamental objectives of sustainable construction includes the criteria related to complete a project in accordance with specified time, cost and quality (Vučković et al., 2014) (Figure 2). Nevertheless, the shortfall of human resource has become the crucial risks that hindering the construction project in achieving sustainability (Awe et al., 2010; Becker \& Smidt, 2015; Levanon et al., 2014).

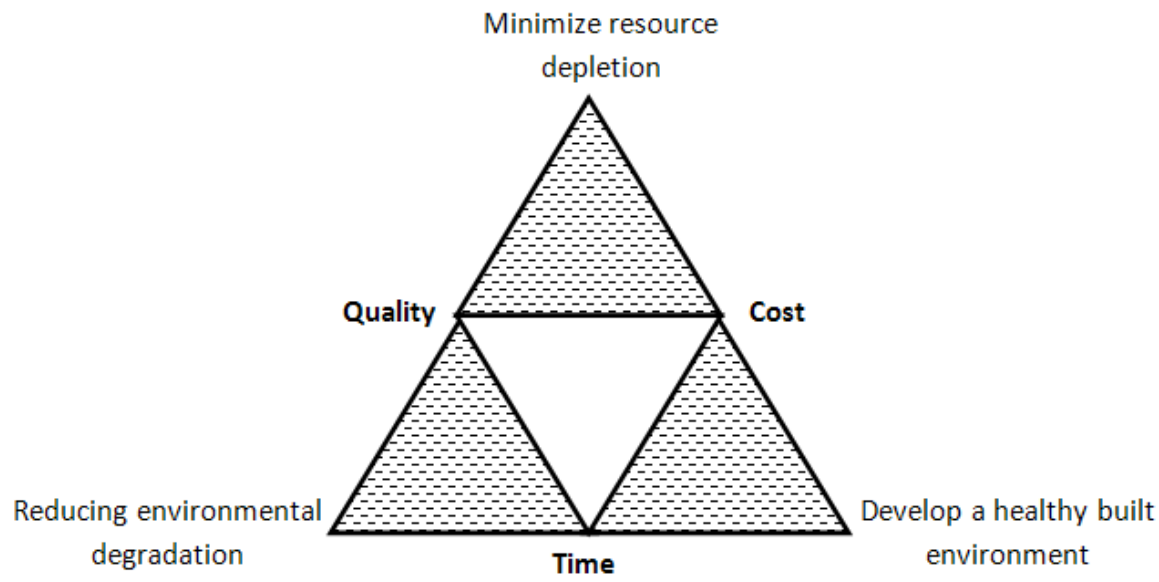

Figure 2: The new paradigm of challenges in sustainable construction Source: (Huovila \& Koskela, 1998)

\section{LABOUR SHORTAGES: FACTORS AND EFFECTS}

A productive economy needs skilled labours to produce prolific services. Yusof \& Misnan (2009) state that the construction industry environment is influenced by the availability and sustainability of skilled and productive labours because it is a labour-intensive industry that relies heavily on human capital. Thus, every person employed within the construction process makes a direct contribution not 
Faizul Azli, Nurul Safwah, Wang Chen, Nurshuhada Zainon, Sumiani Yusoff \& Rafikullah Deraman

The Challenge of Labour Shortage for Sustainable Construction

only to the community in general but also to the nation at large (Ward, 1979). The shortage of labours in the construction industry will give negative impact towards the country's development.

The term "labour shortage" is subject to various interpretations rendered by different authors but basically a labour shortage is refers to an "absolute shortfall in the number of workers in a labour workforce" while at other times it also refers to a "mismatch between worker qualifications and the jobs which are available" (Barnow et al., 2013). In general, it is a situation where the demand for labour in a particular market exceeds the supply. There are some indicators within the industry that may be used to determine the supply and demand forces in the economy. According to Golden (2008), the supply forces within a labour market can be evaluate based on unemployment rate, number of workers unemployed, and job openings reported within the industry, meanwhile the gross domestic product, number of workers employed in the labour market and spending within the industry may be used to evaluate the demand forces.

Labour shortages are often portrayed as a major problem for the economies in many countries (Healy et al., 2015). This can be seen in a report by an international accounting firm, Grant Thornton International, that shows globally there is an average of $39 \%$ shortfall in skilled workers and the figures are higher in Singapore and Malaysia at more than 60\% (Grant Thornton International Ltd, 2012). The Malaysian construction industry is the fourth largest employer utilizing about 1.2 million workers, which is $9 \%$ of the country's total labour force (Malaysia Productivity Corporation, 2015). Although construction industry in Malaysia has showed a good performance for the country's economy, this industry actually faced a tight situation in labour market. The risk of labour shortage in Malaysian construction industry can be seen with the escalating number of the foreign workers in construction site (Salleh et al., 2014).

In line with its role in ensuring the sustainability of the construction industry, it is important to identify the chain of circumstances of labour shortage in the construction project. Based on reported studies, the facts were well clarifies the reasons for the shortage of labour in the construction project. The most obvious reason for the shortage of labour is due to the inability to attract new talent when there is an increasing demand within the workforce. Hamid et al. (2013) report that youth's aversion to low status works, expanding to manufacturing sector which offer better employment conditions, labour attrition, the widening opportunities for tertiary education, lower birth rate, and emigration of workers to high-wage countries are among factors that contribute to construction labour shortage in Malaysia. Furthermore, the existence of "dirty, difficult and dangerous (3D)" image that have always been associated with this industry has indirectly discouraged many local and new graduates to stay away from entering the construction industry, thus resulting in the shortage of labours (Hamid et al., 2013). 
PLANNING MALAYSIA

Sustainable Urban Development

Salleh et al. (2014) identify many factors as having influence on local labour shortage, these include: poor images of construction jobs, poor working conditions, poor site accommodations and services, low wage structure for construction jobs, unattractive jobs, higher education levels, lack of training and skill formation, and skilled workers lured overseas. Healy et al. (2015) find that skill labour shortage get influenced by causes such as specialist knowledge, unsure of long term demand for products or service, recruitment too slow, wages or salary costs too high, lack of availability of adequate training and geographic location of the projects.

Watson (2012) examines the underlying issues surrounding skill shortages in the Australian construction industry and found the funding contributions made to training and skill development, low-level investment to education and training, less investment in apprenticeship system, imbalanced level of labour supply and demand, ageing workforce, and industrial relations, immigration and migration are among factors that have significant effect on labour availability in construction industry. Table 1 is a list of factors of construction labour shortages from previous studies.

Table 1: Factors of labour shortages from previous research

\begin{tabular}{|c|c|}
\hline Factors & Previous research \\
\hline - $\quad$ Ageing workforce & Chini et al. (1999); Mahlberg et al. (2013). \\
\hline $\begin{array}{l}\text { - Change in skill requirements/new } \\
\text { technology }\end{array}$ & $\begin{array}{l}\text { Awe et al. (2010); Chini et al.(1999); Healy et } \\
\text { al. (2015); Lill (2009); Oseghale et al.(2015); } \\
\text { Salleh et al. (2014). }\end{array}$ \\
\hline - Dissatisfaction with labour organization & Lill (2008); Oseghale et al.(2015). \\
\hline - Economy change & $\begin{array}{l}\text { Awe et al. (2010); Chini et al. (1999); Zaki et } \\
\text { al.(2012); Watson (2012). }\end{array}$ \\
\hline - Geographic location & Healy et al. (2015). \\
\hline - High education level & Hamid et al. (2013); Salleh et al. (2014). \\
\hline - Increase demand of craft workers & Watson (2012). \\
\hline $\begin{array}{l}\text { - Lack of job security/high mobility/poor } \\
\text { treatment }\end{array}$ & $\begin{array}{l}\text { Hamid et al. (2013); Lill (2008); Oseghale et al. } \\
\text { (2015). }\end{array}$ \\
\hline - Low number of new entrants & $\begin{array}{l}\text { Chini et al. (1999); Healy et al. (2015); Ismail } \\
\text { \& Yuliyusman (2014); Watson (2012). }\end{array}$ \\
\hline - Low wages/salary & $\begin{array}{l}\text { Chini et al. (1999); Ismail \& Yuliyusman } \\
\text { (2014); Salleh et al.(2014); Zaki et al (2012). }\end{array}$ \\
\hline - Not meeting employer expectation & $\begin{array}{l}\text { Awe et al.(2010); Ismail \& Yuliyusman (2014); } \\
\text { Zaki et al. (2012). }\end{array}$ \\
\hline - $\quad$ Poor education/training & $\begin{array}{l}\text { Awe et al. (2010); Chini et al. (1999); Ismail \& } \\
\text { Yuliyusman (2014); Lill (2008); Oseghale et al. } \\
\text { (2015); Salleh et al. (2014); Watson (2012). }\end{array}$ \\
\hline - Poor construction industry image & $\begin{array}{l}\text { Chini et al. (1999); Hamid et al. (2013); Lill } \\
\text { (2008); Oseghale et al. (2015); Salleh et al. } \\
\text { (2014). }\end{array}$ \\
\hline - Poor site safety/working environment & $\begin{array}{l}\text { Ismail \& Yusliman (2014); Lill (2009); } \\
\text { Oseghale et al. (2015); Salleh et al. (2014); Zaki } \\
\text { et al. (2012). }\end{array}$ \\
\hline
\end{tabular}


Faizul Azli, Nurul Safwah, Wang Chen, Nurshuhada Zainon, Sumiani Yusoff \& Rafikullah Deraman

The Challenge of Labour Shortage for Sustainable Construction

- $\quad$ Skill workers migrate overseas

- Unattractive job/lack of worker-oriented career path
Hamid et al. (2011); Lill (2008); Salleh et al. (2014).

Awe et al. (2010); Hamid et al. (2013); Healy et al. (2015); Ismail \& Yuliyusman (2014); Salleh et al. (2014); Zaki et al. (2012).

Labour shortage is one of the most important risks in construction projects that may affect the project performance (Baloyi \& Bekker, 2011; Othman, 2014), which it capable to change successful projects to those with excessive cost and schedule overruns. Hwang et al. (2015) explored the factor impacting schedule performance of green building projects in Singapore, and found the availability of labourers as one of the most influential factors. Shortage of skilled labour is among the major construction risks considered by general contractors operating in Qatar (Jarkas \& Haupt, 2015) as the factor contributing to construction delay. According to REHDA (Real Estate Housing Developer's Association) in Malaysia, the skilled labour shortage is the one of factor contributing of the increasing property price (The Star Online, 2011). The construction labour shortage in Malaysia also has make the industry rely heavily on foreign labours from outside, especially Indonesia and Bangladesh (Hamid et al., 2013).

\section{SUSTAINABLE MANAGEMENT OF CONSTRUCTION LABOUR}

In general, the way construction works are planned, scheduled and controlled depends directly on the existence of labours in the construction project. Hence, the labours involves with construction project must be treated as a valuable unreproducible resources with vulnerable and unpredictable behavior (Lill, 2008). Apart from the development of sustainable building technology and building materials, the responsible party must also focus on labour management strategy in order to achieve sustainability in the construction industry. There are some features that could become the basis during preparing a strategy to manage labour shortages in the construction industry, for example; via educational and training programme.

In order to overcome the issue of labour shortage and unskilled workmanship, one of the initiatives is by introducing the technical and vocational skills training and education (Chini et al., 1999; Karib et al., 2014; Zaki et al., 2012). According to Olsen \& Tatum (2012) one of the possible solutions to the skilled labour shortages lies within vocational educations. The vocational education and training system has crucial role in supporting with the matching of the skills needed by industry with the skills offered by the labours (Richardson, 2009).

There is a wide variety of technical and vocational training programs available nowadays. For example, in fulfilling the objective of providing construction skilled labour, the Construction Industry Development Board 
(CIDB) Malaysia has established six training centres known as Malaysia Construction Academy and accredited forty private training centres. These training centres have responsibility in providing training to both the existing labours and new labours, focusing on high end specialist trades (e.g. crane operation, welding, painting, and etc.) which has the potential to raise the employability of workers towards earning high wages (Karib et al., 2014). The quality of labours is improved through accreditation and certification under the CIDB Act 520 (Amended 2011).

The production of multi-skilled labours is also an initiative in sustainable construction. Lill (2009) indicated that multiskilling are labour cost savings and fewer workers needed, thus it enables increase in average employment duration. Multi-skilled labours also can generate more saving when they are properly utilized due to lower turnover rates, improved workload and less accidents (Haas et al., 2001). Multi-skilled labour are loyal to their employer because they stay longer on a project and have broader variety of skills (Lill, 2008).

Another strategy to managing labour shortage is by changing the way the work is done. This can be done by substitution of capital and new technology to economise on the shortage of labour (Richardson, 2009). The use of technology is very important for increasing productivity among the limited number of workers, such as by maximizing routine work so that they can perform their specialized tasks that required specific skills.

\section{CONCLUSION}

Sustainable construction means the integration of environmental, social and economic considerations into construction business strategies and practices. Sustainable means durable, thus sustainable labours are those which are prepared to fulfil the needs of present time and to preserve the needs for prospective. The sustainability of construction industry is influenced by the availability of skilled and productive labours because it is a labour-intensive industry that relies heavily on human capital. Due to its importance, the construction industry must ensure the availability of sufficient labour in every project. However, managing labour shortage is more difficult to correct than the lack of material. Past researches have revealed a number of factors that caused labour shortage in construction project. Some of the factors are lack of training and skill knowledge, unattractive and poor images of construction jobs, low salary, and the changes in skill requirements or skill mismatch. In addition, another critical factor is that many young people do not want to do the "3D works" related to the construction project. As the construction activities involve majority of works that are dangerous and difficult, the recruitment and retention of labour become very difficult due to the nature of the work. The lack of sufficient labour in the construction industry needs to be managed seriously as it can affect the productivity of the industry. Therefore, the best strategy to address the shortage of skilled labour lies within the program of 
Faizul Azli, Nurul Safwah, Wang Chen, Nurshuhada Zainon, Sumiani Yusoff \& Rafikullah Deraman

The Challenge of Labour Shortage for Sustainable Construction

technical education and vocational training, because if education and training failed to provide the labours who is required by the industry, the other issues in sustainable construction becomes irrelevant.

\section{REFERENCES}

Ahmed, S.M., Azhar, S., Kappagntula, P. \&Gollapudil, D. (2003). Delays in construction: a brief study of the Florida construction industry, Proceedings of the 39th Annual ASC Conference, April 10-12, Clemson University, Clemson, South Carolina, 257-266.

Assaf, S.A. \& Al-Hejji, S. (2006). Causes of delay in large construction projects. International Journal of Project Management, 24(4), 349-357.

Awe, E. M., Stephenson, P. \& Griffith, A. (2010). Impact of vocational training on skilled labour shortage within Nigerian construction sector. Paper presented at the $C I B$ World Congress 2010, May 10 - 13, Salford Quays, UK.

Baloyi, L. \& Bekker, M. (2011). Causes of construction cost and time overruns: The 2010 FIFA World Cup stadia in South Africa. Acta Structilia, 18(1), 51-67.

Barnow, B. S., Trutko, J. \& Piatak, J. S. (2013). Occupational Labor Shortages: Concepts, Causes, Consequences and Cures. Kalamazoo, MI: W.E. Upjohn Institute for Employment Research.

Becker, K. \& Smidt, M. (2015). Workforce-related risks in projects with a contingent workforce. International Journal of Project Management, 33, 889-900.

Bourdeau, L. (1999). Sustainable development and the future of construction: a comparison of visions from various countries. Building Research \& Information, 27(6), 354-366.

Chini, A. R., Brown, B. H. \& Drummond, E. G. (1999). Causes of the construction skilled labour shortage and proposed solution. Paper presented at the ASC Proceedings of the 35th. Annual Conference, California Polytechnic State University, San Luis Obispo, California.

Delnavaz, M. (2012). Project Managers' Role in Sustainable Building Process. (Master's thesis), Chalmers University of Technology, Göteborg, Sweden.

Department of Statistics Malaysia. (2014). Gross Domestic Product Second Quarter 2014 Retrieved from https://www.statistics.gov.my/index.php?r=column/cthemeByCat \&cat=100\&bul_id=UGI3UnhXZ2lrY1k2eGRITIJSOD1QZz09\&menu_id=TE5CR UZCblh4ZTZMODZIbmk2aWRRQT09

Golden, S. K. (2008). Immigration and Construction: An Analysis of the Impact of Immigration on Construction Project Costs. (Doctoral degree), University of Maryland, Washington, D.C.

Grant Thornton International Ltd. (2012). The Global Economy in 2012: A Rocky Road to Recovery. Retrieved from http://www.grantthornton.global/en/insights/ articles/global-economy-2012/

Haas, C. T., Rodrigues, A. M., Glover, R. \& Goodrum, P. M. (2001). Implementing a multiskilled workforce. Construction Management and Economics, 19, 633-641.

Hajela, R. (2012). Shortage of skilled workers: A paradox of the Indian economy. SKOPE Research Paper, 111, 1-24.

Hamid, A. R. A., Singh, B. S. B. J. \& Mazlan, M. S. (2013). The construction labour shortage in Johor Bahru, Malaysia. International Journal of Research in Engineering and Technology, 2(10), 508-512.

Healy, J., Mavromaras, K. \& Sloane, P. J. (2015). Adjusting to skill shortages in Australian SMEs. Applied Economics, 47(24), 2470-2487. 
Horvath, A. (2004). Construction materials and the environment. Annual Review of Environment and Resources, 29, 181-204.

Huovila, P. \& Koskela, L. (1998). Contribution of the principles of lean construction to meet the challenges of sustainable development. Paper presented at the 6th Annual Conference on Lean Construction, August 13-15, Guaruja, Brazil.

Hussin, J. M., Rahman, I. A. \& Memon, A. H. (2013). The way forward in sustainable construction: Issues and challenges. International Journal of Advances in Applied Sciences, 2(1), 15-24.

Hwang, B.-G., Zhao, X. \& Tan, L. L. G. (2015). Green building projects: schedule performance, influential factors and solutions. Engineering, Construction and Architectural Management, 22(3), 327-346.

Ibrahim, M. (2013). Contractors' perspective toward factors affecting labor productivity in building construction. Engineering, Construction and Architectural Management, 20(5), 446-460.

Ismail, R. \& Yuliyusman, F. (2014). Foreign labour on Malaysian growth. Journal of Economic Integration, 29(4), 657-675.

Jarkas, A. M. \& Haupt, T. C. (2015). Major construction risk factors considered by general contractors in Qatar. Journal of Engineering, Design and Technology, 13(1), 165194.

Jarkas, A. M. \& Younes, J. H. (2014). Principle factors contributing to construction delays in the State of Qatar. International Journal of Construction Project Management, 6(1), $39-62$.

Karib, S. A., Shaffii, N., Soh, C. S. C. \& Abidin, N. I. Z. (2014). Meeting construction industry resources requirements: The Malaysia way. Paper presented at the 20th Asia Construct Conference, November 13-14, Hong Kong.

Kibert, C. (2005). Sustainable construction: Green building design and delivery. New Jersey: John Wiley \& Sons.

Levanon, G., Cheng, B. \& Paterra, M. (2014). The risk of future labor shortages in different occupations and industries in the United States. Business Economics, 49(4), 227243.

Lill, I. (2008). Sustainable management of construction labour. Paper presented at the 25th International Symposium on Automation and Robotic in Construction, June 26-29, Lithuania.

Lill, I. (2009). Multiskilling in construction - A strategy for stable employment. Technological and Economic Development of Economy, 15(4), 540-560.

Lozano, R. (2008). Envisioning sustainability three-dimensionally. Journal of Cleaner Production, 16, 1838-1846.

Mahlberg, B., Freund, I., Crespo Cuaresma, J. \& Prskawetz, A. (2013). Ageing, productivity and wages in Austria. Labour Economics, 22(0), 5-15.

Malaysia Productivity Corporation (2015). Productivity Performance of the Construction Sector. Retrieved from http://www.mpc.gov.my/wp-content/uploads/ 2016/04/Productivity-Report-201415.pdf

Mateus, R. \& Bragança, L. (2011). Sustainability assessment and rating of buildings: Developing the methodology SBToolPTeH. Building and Environment, 46, 1962 1971.

Olsen, D. \& Tatum, M. C. (2012). Bad for business: Skilled labor shortages in Alabama's construction industry. Paper presented at the 48th ASC Annual International Conference Proceedings, April 11-14, Birmingham, UK. 
Faizul Azli, Nurul Safwah, Wang Chen, Nurshuhada Zainon, Sumiani Yusoff \& Rafikullah Deraman

The Challenge of Labour Shortage for Sustainable Construction

Oseghale, B. O., Dr Abiola-Falemu, J. O. \& G.E, O. (2015). An evaluation of skilled labour shortage in selected construction firms in Edo State, Nigeria. American Journal of Engineering Research, 4(1), 156-167.

Othman, A. A. E. (2014). A conceptual model for overcoming the challenges of mega construction projects in developing countries. African Journal of Engineering Research, 2(4), 73-84.

Rahman, I. A., Memon, A. H. \& Karim, A. T. A. (2013). Significant factors causing cost overruns in large construction projects in Malaysia. Journal of Applied Sciences, 13(2), 286-293.

Richardson, S. (2009). What is a skill shortage? Australian Bulletin of Labour, 35(1), 326354.

Salleh, N. M., Mamter, S., Lop, N. S., Kamar, I. F. M. \& Hamdan, N. A. M. (2014). The escalating of numbers of foreign workers in construction site. Paper presented at the Building Surveying, Facilities Management and Engineering Conference (BSFMEC 2014), August 27, Perak, Malaysia.

Suliman, L. K. M. \& Omran, A. (2009). Sustainable development and construction industry in Malaysia. Manager, 10, 76-85.

United Nations (1987) Our Common Future - Brundtland Report. Oxford University Press.

The Star Online. (2011, June 25). Your 10 questions with Datuk Seri Michael Yam. The Star Online.

Vučković, A., Mihić, M. \& Petrović, D. (2014). Human resource management as a project success factor - studies review. Serbian Project Management Journal, 4(1), 62-71.

Wang, N. (2014). The role of the construction industry in China's sustainable urban development. Habitat International, 44, 442-450.

Ward, P. A. (1979). Organization and Procedures in the Construction Industry. Great Britain Macdonald and Evans Ltd.

Watson, M. (2012). Concerns for skills shortages in the 21st century: a review into the construction industry, Australia. Australasian Journal of Construction Economics and Building, 7(1), 45-54.

Windapo, A. O. (2016). Skilled labour supply in the South African construction industry: The nexus between certification, quality of work output and shortages. SA Journal of Human Resource Management, 14(1), doi: 10.4102/sajhrm.v14i1.750.

Yusof, Z. M. \& Misnan, M. S. (2009). Malaysian construction workforce: Whether local youth interested to enroll into training institutions such as Akademi Binaan Malaysia (ABM) to undergo training to be skilled construction workers. Paper presented at the 2nd International Conference on Construction Industry, July 30 - August 1, Padang, Sumatera Barat, Indonesia.

Zaki, S. A., Mohamed, S. F. \& Yusof, Z. M. (2012). Construction skilled labour shortage The challenges in Malaysian construction sector. OIDA International Journal of Sustainable Development, 4(5), 99-108.

Zimmerman, J. B. (2005). EPA's P3-People, Prosperity, and Planet—Award. Sustainability: Science, Practice \& Policy, 1(2), 32-33. 